\title{
Correction: Handoff optimization in 802.11 wireless networks
}

IP Hsieh, Chih-Mou Shih and Shang-Juh Kao*

\section{Correction}

After publication of this work [1], we noted that we inadvertently failed to include the complete list of all coauthors. The full list of authors has now been added and the Authors' contributions and Competing interests section modified accordingly.

\section{Authors' contributions}

SJK prepared for the manuscript and study coordination; IPH prepared for building up the experimental environment and execution; CMS prepared for the data analysis and evaluation.

\section{Competing interests}

The authors declare that they have no competing interests.

Received: 22 July 2011 Accepted: 22 July 2011 Published: 22 July 2011

\section{Reference}

1. IP Hsieh, SJ Kao, Handoff optimization in 802.11 wireless networks. EURASIP Journal on Wireless Communications and Networking. 2011, 30 (2011)

Submit your manuscript to a SpringerOpen ${ }^{\bullet}$ journal and benefit from:

- Convenient online submission

- Rigorous peer review

- Immediate publication on acceptance

- Open access: articles freely available online

- High visibility within the field

- Retaining the copyright to your article

Submit your next manuscript at $\gg$ springeropen.com

\section{SpringerOpen $^{\circ}$}

(C) 2011 Hsieh et al; licensee Springer. This is an Open Access article distributed under the terms of the Creative Commons Attribution License (http://creativecommons.org/licenses/by/2.0), which permits unrestricted use, distribution, and reproduction in any medium, provided the original work is properly cited. 